\title{
The impact of team dialogue sessions on employee engagement in an information and communication technology company
}

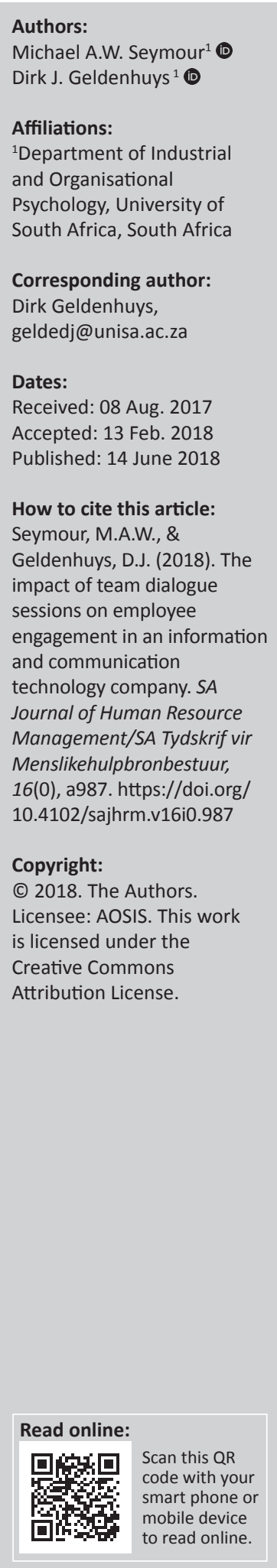

Orientation: Engaged employees are regarded as extremely valuable in today's unstable economic environment. However, despite spending large amounts of money on the improvement of employee engagement, the effect thereof is seldom determined. This study was about determining the impact of team dialogue sessions on the enhancement of employee engagement in a large information and communication technology company over a 2-year period.

Research purpose: This study focused on determining the improvement of employee engagement through an organisation development intervention. The intervention was based on a social constructionist perspective, namely, team dialoguing, and was facilitated over a period of two years.

Motivation for the study: Although the matter regarding the improvement of employee engagement seems to be extensively discussed in the literature, research on the use of interventions to enhance employee engagement is to a large extent still lacking. Based on a theoretical integration, it was argued that team dialoguing could improve employee engagement.

Research design, approach and method: This was a quantitative study, employing a quasiexperimental design. An experimental group was exposed to an organisation development intervention of team dialogues over a 2-year period and then compared to a control group that had not been exposed to the intervention.

Main findings: Although with a small effect size, it was discovered that facilitating team dialogue sessions had a positive impact on employee engagement, more specifically on the exercise of discretionary effort, intention to remain, rational commitment, communication and supervisory support as dimensions.

Practical and managerial implications: The practical implication of this study is that the engagement of employees can be enhanced by involving the direct supervisor and his or her team in dialoguing sessions.

Contribution or value-add: The study contributed to the literature on employee engagement by reporting on the implementation of an intervention over a period of two years to enhance employee engagement.

\section{Introduction}

This study concerns the impact of team dialogue on employee engagement. The importance of employee engagement is not disputed in the literature, especially in publications in journals referring to its benefits and overall contribution to organisational effectiveness (Markos \& Sridevi, 2010). For instance, according to Dick (2007), engaged employees are more motivated, responsive to change and more willing to perform different demanding work activities. Furthermore, Robinson, Perryman and Hayday (2004) state that engaged employees are more productive, make more money for the company and create emotional engagement by loyal customers. They contribute to good organisational climate where people are productive, ethical and accountable. They remain with the organisation for a longer period and are more committed to quality and growth than non-engaged and actively disengaged employees. Recently, Gupta

Note: This article is largely based on the author's dissertation of the degree of Master of Commerce in Industrial and Organisational Psychology at the University of South Africa, South Africa, with supervisor Prof Dirk Geldenhuys, received February 2015, available here: http://uir.unisa.ac.za/bitstream/handle/10500/19179/dissertation_seymore_maw.pdf?isAllowed=y\&sequence=1 
and Sharma (2016) emphasised the crucial role of employee engagement in the volatile economic world. For instance, they referred to research findings indicating that employee engagement was found to be a significant predictor of productivity, retention, customer satisfaction and, also shareholder return.

The manager plays a crucial role in representing the organisation for the employee [Bakker, 2017; Corporate Leadership Council (CLC), 2004]. Dick (2007), for example, referred to the research findings indicating that where employees trusted their managers, liked their leadership styles and perceived them as competent, they aligned with the company's values and were honoured to be a member of the company.

Although the matter regarding the improvement of employee engagement seems to be extensively discussed in the literature, research on the use of interventions to enhance employee engagement is largely still lacking (Van der Colff \& Rothmann, 2009). This is especially true for applying interventions that are based on social constructionism, such as team dialogue sessions (Geldenhuys, 2015). The rationale in this article is that organisation development (OD) interventions that are based on social constructionism, more specifically team dialogue sessions, can be used to enhance employee engagement. Camargo-Borges and Rasera (2013) indicated that social constructionism, with its focus on concepts such as dialogue, imagination, co-creation and meaning-making, introduced new ways of working with teams in organisations by studying and analysing the interconnectedness of, and mutual influence between, team members. These authors are therefor of the opinion that social constructionism offers new opportunities for organisational interventions that may be used by managers, consultants and group leaders alike.

\section{Research objective}

The purpose of this study was to determine the impact of dialogue sessions on employee engagement in work teams over a 2-year period.

The theoretical framework that follows served as the basis for the study, the research design, the reporting of the results and the discussion thereof.

\section{Employee engagement}

The study of employee engagement has led to the development of four main research directions (Simpson, 2009). Firstly, employee engagement is regarded as personal engagement, a concept introduced by Kahn (1990). Kahn reasoned that engagement is a multidimensional construct where employees can be emotionally engaged (psychological safety), physically engaged (psychologically availability) and cognitively connected with their work roles (psychological meaningfulness), with cognitive and emotional engagement as the two major dimensions. Kahn (1990, p. 694) subsequently defines employee engagement as 'the harnessing of organisation members' selves to their work roles; in engagement, people employ and express themselves physically, cognitively and emotionally during role performances'. It is therefore the result of being psychologically present when occupying and performing an organisational role. Workers are likely to be more engaged in situations that allow them to experience more psychological meaningfulness and psychological safety, as well as when the workers are more psychologically available (Kahn, 1990). In a field study conducted by May, Gilson and Harter (2004), who furthered the work of Kahn, support was found for the relationship between engagement and all three psychological conditions.

Secondly, employee engagement is regarded as the positive antithesis of burnout. This line of reasoning was developed by Maslach, Schaufeli and Leiter (2001) and Leiter and Maslach (2004). Maslach et al. (2001, p. 417) defined employee engagement as 'a persistent, positive affective-motivational state of fulfilment'. According to Maslach et al., employee engagement is characterised by the direct opposites of the three burnout dimensions (exhaustion, cynicism and inefficacy), namely energy, involvement and efficacy.

Thirdly, the study of employee engagement is based on the conceptualisation of Schaufeli and Bakker (2004), who preferred to use the term 'work engagement'. Engagement is regarded as a positive, fulfilling, work-related state of mind characterised by vigour, dedication and absorption (Schaufeli, Salanova, González-Romá, \& Bakker, 2002). Vigour refers to high levels of energy, mental resilience and a willingness to put effort into one's work. Dedication is associated with enthusiasm, inspiration, pride, challenge and a sense of significance; and absorption refers to a state where time passes quickly and where the employees find it difficult to detach themselves from work (Schaufeli et al., 2002).

Schaufeli et al. (2002) reasoned that vigour is the opposite of emotional exhaustion, dedication is the opposite of cynicism and absorption is a third component of work engagement. Furthermore, Schaufeli and Bakker (2004) reasoned that both engagement and burnout can be integrated into a comprehensive and overarching framework, which they coined as the job demands resources model (JDR model). According to the JDR Model, work engagement is a function of the demands of the job and resources provided by the organisation. Engagement is at its highest when employees experience interesting job demands but simultaneously have access to sufficient job resources (Bakker, 2017).

Finally, the concept as developed by Harter, Hayes and Schmidt (2002) entails job satisfaction, involvement and enthusiasm, a set of motivating resources, such as recognition and support from managers and colleagues, performance feedback, and opportunities for learning and development. This concept was measured using the Gallup Work Audit.

According to Erikson (2004), employee engagement is not only about job satisfaction but also involves aspects such as 
commitment, loyalty and pride in the organisation, a willingness to advocate for the organisation and a sense of personal responsibility. Employee engagement therefore entails discretionary effort where employees decide whether to do their very best and put in extra effort, or just do the bare minimum of what is expected of them.

Therefore, it seems that there is no consensus on conceptualising employee engagement and hence the dimensions thereof (Bakker, 2011; Gupta \& Sharma, 2016). For the purpose of this study, employee engagement refers to the degree to which employees demonstrate discretionary effort (willingness to go 'above and beyond' the call of duty), as well as their intention to remain employed in that organisation (CLC, 2004). Employee engagement includes the extent to which an employee displays rational commitment, that is, the degree to which employees are of the opinion that managers, teams and their organisation have their interests at heart. It also includes emotional commitment, that is, the degree to which employees believe in, value and enjoy their jobs. Highly engaged employees are more likely to remain with their current organisation, to be productive and to engage more positively with customers than employees with lower engagement levels.

From the above discussion on the perspectives on employee engagement, the following dimensions of employee engagement have been identified for the purpose of this study.

Discretionary effort: Referring to doing one's very best and putting in extra effort that promotes the effectiveness of the organisation without explicitly being rewarded for their efforts by the formal system (Erikson, 2004; Kahn, 1990; Organ, 1997).

Turnover intention: Tett and Meyer (1993, p. 262) defined turnover intention as the 'conscious and deliberate willingness to leave the organisation'. It has also been described as 'the last in a sequence of withdrawal cognitions, a set to which thinking of quitting and intent to search for alternative employment also belong' (Tett \& Meyer, 1993, p. 262). Withdrawal behaviour is the primary way in which employees deal with issues in the employment relationship (Lo \& Aryee, 2003).

Emotional commitment: Kahn (1990) suggests that engagement relates to the emotional engagement (psychological safety) of employees. Rothbard (2001) considers engagement to have a dimension of psychological presence 'absorption', while Schaufeli (2013) and Bakker (2004) consider employee engagement to be a positive and rewarding state of mind. Psychological safety is defined as 'feeling able to show and employ one's self without fear of negative consequences to selfimage, status, or career' (Kahn, 1990, p. 703). In addition, employee engagement involves the active use of 'emotions and behaviours' (May et al., 2004, p. 12).

Rational commitment: Saks (2006) states that engagement has cognitive behavioural components associated with individual role performance, while Kahn (1990, p. 694) maintains that 'people employ and express themselves cognitively in role performances'. May et al. (2004, p. 12) agree with Kahn (1990) and introduce 'psychological meaningfulness', 'the value of a work goal or purpose' and 'a primary motive to seek meaning in their work'. Rothbard (2001, p. 656), on the other hand, refers to 'cognitive availability and the amount of time one spends thinking about a role'.

Communication: Two-way, open communication forms a fundamental part of employee engagement (Erikson, 2004).

Perceived supervisory support: The crucial role played by supervisors in employee engagement is emphasised by Dick (2007), referring to research findings indicating that where employees trusted their supervisors, liked their management styles and were of the view that they were competent, they shared the company's values and were proud to be employed by the company.

Perceived team support: May et al. (2004) also found that coworker relations were positive predictors of employee engagement.

For the purpose of this study and based on the work conducted by the CLC (2004), discretionary effort and turnover intention are regarded as the main constructs of employee engagement.

\section{Team dialogue}

The word 'dialogue' has two Greek roots: dia (meaning 'through' or 'with each other') and logos (meaning 'the word') (Isaacs, 1994). Dialogue is 'the art of thinking together' and is 'a sustained collective inquiry' into everyday experience, and what we take for granted (Isaacs, 1994, p. 353). According to Ellinor and Gerard (1998), dialogue entails:

[s]eeing the whole rather than breaking it into parts; seeing connections rather than distinctions; inquiring into assumptions rather than justifying or defending them; learning through inquiry and disclosure rather than persuading, selling or telling; and creating shared meanings rather than gaining agreement on one meaning. (p. 21)

Dialoguing is based on social constructionism as ontological and epistemological underpinning and explores the manner in which knowledge is embedded in cultural values and practices. Meanings are socially constructed through the coordination of people in their various encounters (Camargo-Borges \& Rasera, 2013).

There is a difference between dialoguing and debating, discussing or persuasion. In a debate, there is normally a clash of opinions and positions where the most rational argument is regarded as superior. Persuasion, however, takes a milder approach, with the aim of finding convincing ways to influence people to make a choice. Dialogue, in contrast, constructs a space for conversation that welcomes participants 
to invite a multiplicity of voices. It is a process that is intimately connected with the co-creation of new realities (Gergen, McNamee, \& Barrett, 2002). It is not focused on finding the 'right way' or 'the only way' of doing things, but on finding ways to generate and create opportunities for people to feel connected and willing to participate.

Furthermore, dialogue is also different from consensus building (Isaacs, 1994). While consensus building often seeks to limit options and find strategies that are acceptable to most people, dialogue seeks to surface fundamental assumptions and an understanding of why they arise. Dialogues allow, through sharing, to externalise what is on a person's mind and eventually change the underlying patterns of meaning (Herrera, 2015). The goal of dialogue is not to eliminate differences but to create a space where the differences can coexist and be studied, not be ignored or put aside to arrive at something all parties can agree on.

Dialoguing requires the identification of socially constructed realities or assumptions by means of listening, inquiring and reflecting (Duffy \& Wong, 2016; Gerard \& Teurfs, 1995); bringing similarities and differences into the open for discussion, common understanding and modification (Lau \& Shani, 1992, p. 99); and by respecting other perspectives by suspending judgement (Gerard \& Teurfs, 1995).

Applied to organisations, Duffy and Wong (2016) stated that dialogue is fundamental to organisational learning, for without dialogue individuals and groups cannot exchange ideas effectively, nor can they develop shared understanding. For the Greeks, dialogos meant a free flowing of meaning through a group, allowing the group to discover insights not attainable individually (Senge, 1990).

\section{Theoretical integration}

Based on the literature, it seems that the dimensions of employee engagement that are related to teamwork can be mostly influenced by team dialogue sessions. For instance, Erikson (2004) indicates eight factors that consistently surface as drivers of employee engagement; of these, teamwork, involvement and belonging, open two-way communication, trust and confidence in leadership are directly linked to the team.

Also, according to Maslach et al. (2001), a breakdown of community among team members will weaken their commitment to each other. Without a sense of community, a work team lacks the synergies required for an integrated work group. Moreover, a poor sense of community directly affects productivity and creates a vulnerability to conflict between the group members. Unresolved conflict drains the team members emotionally and thereby influences their emotional commitment (Maslach et al., 2001).

Furthermore, of the six drivers of employee engagement identified by Saks (2006), perceived supervisor and organisational support are particularly important in the team context. When employees feel that they are allowed to reveal their true selves without fearing negative consequences, they gain a sense of psychological safety; this stems from the amount of support that they perceive to be provided by their manager, their work colleagues and the organisation (Kahn, 1990; May et al., 2004; Schaufeli \& Bakker, 2004). This view is supported by Robinson et al. (2004), who reasoned that employees are more engaged in circumstances where there is a good relationship with clear communication from their manager, when they have a clear path set for focusing on what they do best and have strong relationships with and feel a strong commitment to their co-workers, thus enabling them to take risks and stretch for excellence.

May et al. (2004) describe employee engagement in terms of psychological meaningfulness, psychological safety and psychological availability. The workplace dimension related to psychological safety includes supervisory relations, coworker relations, work role insecurities and behavioural norms, which are directly applicable to the team context.

In teams, effective dialogue directly influences the functioning of a team, the communication within a team, the relationships between the team members in a team and the relationship team members have with their supervisor. As stated by Lau and Shani (1992):

One of the basic and most persistent problems of organisational life is that different people see situations, issues, or goals differently, depending on their particular perspectives, experiences, backgrounds, and biases - yet everyone typically assumes that everyone else sees things as they do. (p. 99)

According to Schein (1993, p. 44), 'dialogue aims to build a group that can think generatively, creatively, and most importantly, together', and reasoned that dialogue is revealed when the way in which someone interprets a concept is recognised as being different from one's own; that is, there is a willingness to accept differences in the way that people reason and act under conditions of high uncertainty and high task interdependence can lead to greater levels of understanding of alternative ways of thinking and dedication to a particular worldview.

Robinson et al. (2004) agree that employees are more engaged in circumstances where there is clear communication from their manager. The following noted by Lau and Shani (1992):

Communication dialoguing is one way to overcome contradictory expectations by bringing similarities and differences in perspective out into the open. They can then be discussed, modified by other data or new interpretations, and shared ... Such exchange is the foundation for understanding, trust, and thus effective working relations, and successful managers and employees use it frequently. (p. 98)

\section{Research design Research approach}

This was a quantitative study, using a non-equivalent quasi-experimental design (Cooper \& Schindler, 2011). As volunteers were recruited for the experimental group and non-volunteers were used for the control group, the 
self-selected experimental group design was used as variation of the design (Cooper \& Schindler, 2011). The membership of the experimental group was exposed to the team dialogue intervention over a period of 2 years and compared to a control group that had not been exposed to the dialogue intervention.

The team dialogue intervention was conducted with work teams, including their direct supervisors. All the sessions were facilitated by a human resource (HR) specialist facilitator who was responsible for creating a relational space where dialogue was encouraged. Such dialogue had to be characterised by openness and curiosity, in which conversations could be brought together or coordinated, based on multiple realities, representing various stakeholders with different stories and experiences, bases of power and belief systems. In exploring ways of creating a context that invites dialoguing, the emphasis was on the relational processes between the team members and not on the team members as entities themselves (Geldenhuys, 2015).

The facilitator also had to ensure that the dialogue sessions adhered to the nature of dialoguing such as thinking together, suspending judgement, identifying assumptions, listening, inquiring and reflecting and, finally, collaborative learning. The content of the dialogue sessions not only had to focus on the vision and mission of the company, as well as the core values, but also had to include dialogue on team functioning, communication, team relationships, perceived team support and relationships between team members and their supervisors.

The team dialogue sessions were conducted on a monthly basis and lasted for approximately two hours. During the session, the facilitator took notes, which the team could refer to in the following session.

\section{Research method}

\section{Research participants}

The population for this study comprised all the 23000 individual full-time employees of an information and communication technology (ICT) organisation. The sample for this study numbered 660 employees who participated in the employee engagement surveys conducted before and after participating in team dialogue sessions over this period, which was the experimental group. The control group consisted of 660 randomly selected individual full-time employees who participated in both the employee engagement surveys conducted, but did not participate in the organisation intervention of team dialogue sessions.

The demographic characteristics of the experimental group and the control group are compared in Figure 1. As displayed

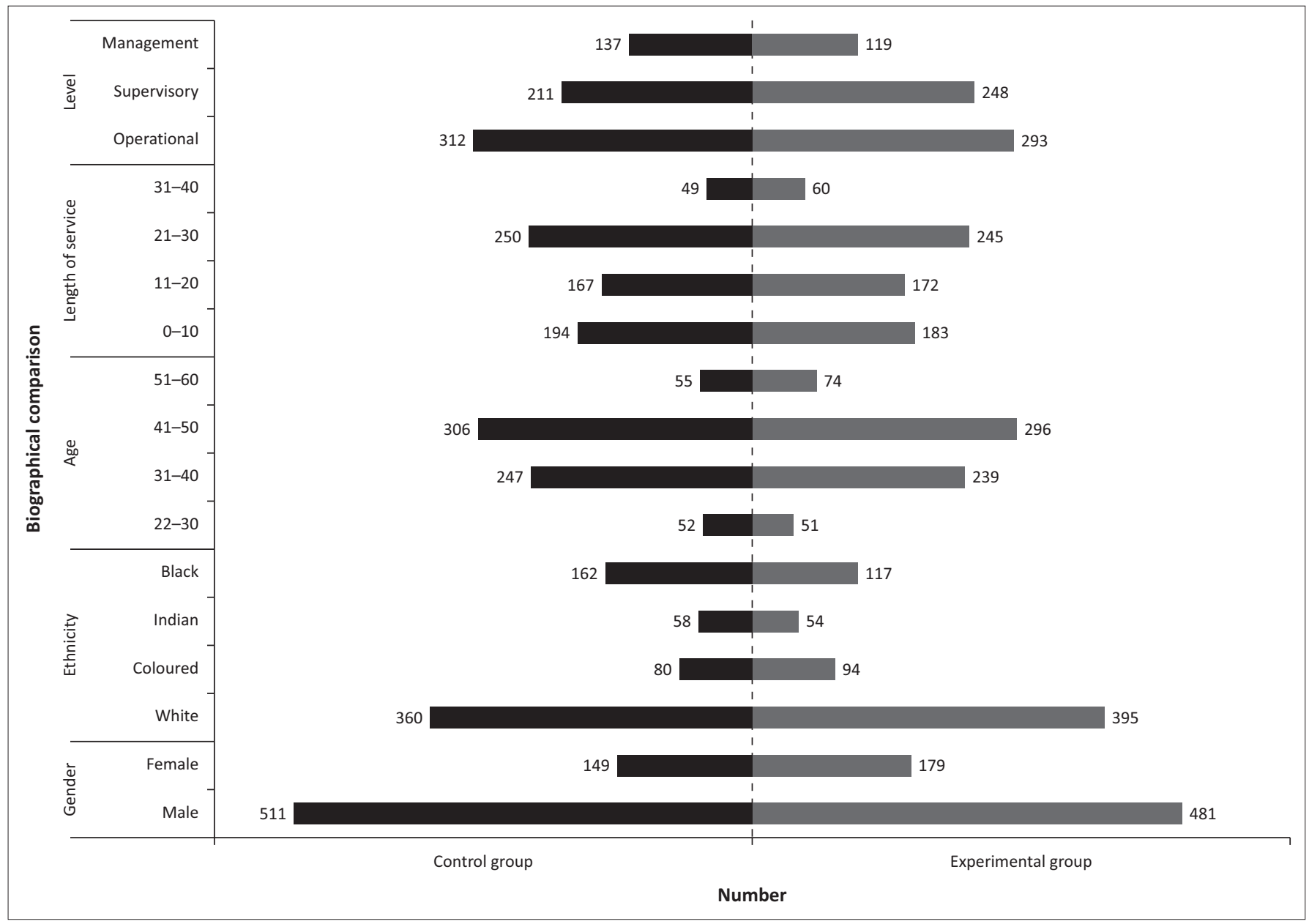

FIGURE 1: Biographical comparison of experimental and control groups. 
in Figure 1, the demographic distribution characteristics of the experimental group and the control group are largely similar. This implies that the differences between the experimental group and the control group can be measured accurately to determine the influence of team dialogue sessions on employee engagement. This also means that the research can reliably use non-parametric tests for comparing the control group and the experimental group.

\section{Measuring instrument}

The employee engagement scale, developed by the CLC, was used as measuring instrument for this study. To validate this survey, several studies of employee engagement were conducted, using this survey questionnaire with more than 50000 employees across the world. Overall, Cronbach's alpha of over 0.70 (CLC, 2004) was reported. The reason for selecting this scale was not only its reliability and validity but also its capability to measure the dimensions as conceptualised for the purpose of this study that might be influenced by team dialogues, namely, emotional commitment and rational commitment, communication, perceived team support and perceived supervisory support, as well as turnover intention and discretionary effort. Respondents had to rate items on a five-point Likert scale, ranging from 1 (strongly disagree) to 5 (strongly agree). The scale for some of the items ranged from 1 (very poor) to 5 (excellent). Provision was also made for 'unable to rate' (0). Examples of the questions asked are presented below:

- Discretionary effort: I am willing to work many additional hours over the next year if it helps achieve its goals.

- Turnover intention: I actively search for job opportunities at other companies.

- Rational commitment: All in all, it I would say 'it is worth it' for my family, my career and for me personally to work here.

- Emotional commitment: Working with ITC has a great deal of personal meaning to me.

- Communication: Overall how would you rate ITC's employee communications?

- Perceived supervisory support: Providing the right amount of supervision and guidance.

- Perceived team support: Being in a section/team you have a strong personal attachment to.

\section{Research procedure}

The institution through which the research was conducted provided ethical clearance for the study. Permission was also obtained from the company and voluntary participation of all participants and confidentiality of all information were assured. A personal invitation was sent out by an e-mail to the entire population, with the Universal Resource Locator (URL) address of the online survey attached. When administering the four employee engagement surveys, a census-based approach was used with the intention of surveying all employees in the heterogenic population (everybody in the target population had an equal opportunity to participate in the survey). These surveys were conducted over a period of 1 month, 2 years apart, before and after the intervention. It should be noted that participation in the intervention was also on a volunteering basis according to the best ethical practice in organisation development (OD) as stipulated in the 'Ethical guidelines for an OD/Human Systems Development (HSD) Professional' as developed by the Human Systems Development Consortium (Cummings \& Worley, 2015, pp. 70-73).

\section{Statistical analysis}

Data captured from the online web-based surveys were analysed, using version 23 of the IBM Statistical Package for the Social Sciences (SPSS). It was decided to make use of nonparametric tests for the analysis of the data as non-parametric tests are less demanding to use, do not specify stringent assumptions such as normally distributed populations or equality of variance (Easton \& McColl, 2004) but still achieve an efficiency as high as 95\% (Cooper \& Schindler, 2011).

Furthermore, the Kolmogorov-Smirnov test was applied to measure the differences in the means between the experimental group and the control group (Easton \& McColl, 2004). This test is often used in organisational studies and is recommended for independent related samples with ordinal data (Brewerton \& Millward, 2001; Cooper \& Schindler, 2011).

\section{Hypotheses}

The following hypotheses were formulated:

- $\mathbf{H}_{\mathbf{0}}$ : Team dialogues have no influence on employee engagement.

- $\mathbf{H}_{\mathbf{1}}$ : Team dialogues have a significant influence on employee engagement.

\section{Results \\ Instrument reliability}

The overall Cronbach's alpha coefficient score of 0.778 that was yielded by the measuring instrument as a whole can be regarded as acceptable (Pallant, 2007). The Cronbach's alpha coefficients for the individual dimensions are presented in Table 1.

All Cronbach's alpha scores (ranging from 0.744 to 0.832 ) are indicative of the acceptable reliability of the measuring instrument (Pallant, 2007).

\section{Descriptive statistics}

The means and standard deviations of the experimental group and the control group, both before and after the intervention, are presented in Table 2.

As shown in Table 2, the experiment had a mean of 3.40 before the intervention, with a mean of 3.51 after the intervention, indicating an improvement after the intervention. Furthermore, the control group is lower on employee engagement than the experimental group, both 
before and after the intervention. A possible explanation for this is that the experimental group volunteered for the intervention and could therefore be positively biased towards the dialogue sessions. According to Sidebottom (2015), some people do not prefer a face-to-face communication. Those employees who do not favour face-to-face communication probably do not volunteer to be part of the intervention.

\section{Non-parametric paired sampling test}

To determine if the two samples may reasonably be assumed to originate from the same distribution, the KolmogorovSmirnov test was used. The results are presented in Table 3.

\section{Non-parametric independent sampling test}

The Wilcoxon signed-rank test was used to measure the differences in the means between the experimental group and the control group (Easton \& McColl, 2004). The results are presented in Table 4 .

The negative rank score in Table 4, for both the experimental group and the control group, indicates a significant difference

TABLE 1: Cronbach's alpha coefficient scores.

\begin{tabular}{lc}
\hline Factor & Cronbach's alpha coefficient \\
\hline Employee engagement & 0.832 \\
Discretionary effort & 0.754 \\
Turnover intention & 0.770 \\
Rational commitment & 0.746 \\
Emotional commitment & 0.744 \\
Communication & 0.749 \\
Perceived supervisory support & 0.753 \\
Perceived team support & 0.749 \\
\hline
\end{tabular}

TABLE 2: Descriptive statistics.

\begin{tabular}{|c|c|c|c|c|c|}
\hline Sample group & $N$ & Mean & Std. deviation & Minimum & Maximum \\
\hline $\begin{array}{l}\text { Experimental } \\
\text { before }\end{array}$ & 660 & 3.40 & 0.76 & 1 & 5 \\
\hline $\begin{array}{l}\text { Experimental } \\
\text { after }\end{array}$ & 660 & 3.51 & 0.74 & 1 & 5 \\
\hline Control after & 660 & 1.75 & 1.21 & 1 & 4 \\
\hline $\begin{array}{l}\text { Control } \\
\text { before }\end{array}$ & 660 & 1.88 & 1.19 & 1 & 4 \\
\hline Total group & 1320 & 1.50 & 0.500 & 1 & 2 \\
\hline
\end{tabular}

TABLE 3: Hypothesis test summary.

\begin{tabular}{llll}
\hline Number & Null hypothesis & Test & Sig. \\
\hline 1 & $\begin{array}{l}\text { Distribution of the experimental group before the intervention } \\
\text { with a mean of 3.40 and a standard deviation of 0.76 }\end{array}$ & $\begin{array}{l}\text { One-sample } \\
\text { Kolmogorov-Smirnov test }\end{array}$ & $<0.001$ \\
2 & $\begin{array}{l}\text { Distribution of the experimental group after two years with } \\
\text { a mean of 3.51 and a standard deviation of 0.74 }\end{array}$ & $\begin{array}{l}\text { One-sample } \\
\text { Kolmogorov-Smirnov test }\end{array}$ & $<0.001$ \\
\hline
\end{tabular}

Sig., significance.

TABLE 4: Wilcoxon ranks table.

\begin{tabular}{|c|c|c|c|c|c|c|c|c|}
\hline Group & Timing & Ranks & $N$ & Mean rank & Sum of ranks & $Z$ & $P$ & Effect size $\eta^{2}$ \\
\hline \multirow[t]{4}{*}{ Experimental } & \multirow{4}{*}{$\begin{array}{l}\text { After intervention } \\
\text { Before intervention }\end{array}$} & Negative ranks & 106 & 134.38 & 14244.00 & -3.943 & $<0.001$ & 0.024 \\
\hline & & Positive ranks & 168 & 139.47 & 23431.00 & - & - & - \\
\hline & & Ties & 386 & - & - & - & - & - \\
\hline & & Total & 660 & - & - & - & - & - \\
\hline \multirow[t]{3}{*}{ Control } & \multirow{3}{*}{$\begin{array}{l}\text { After intervention } \\
\text { Before intervention }\end{array}$} & Negative ranks & 103 & 129.04 & 13291.00 & -3.927 & $<0.001$ & 0.024 \\
\hline & & Positive ranks & 163 & 136.32 & 22220.00 & - & - & - \\
\hline & & Total & 660 & - & - & - & - & - \\
\hline
\end{tabular}

between before the intervention and two years thereafter, and an improvement in the employee engagement rating. The negative rank score for the experimental group $\left(Z=-3.942, p<0.001, \eta^{2}=0.024\right)$ indicates a higher score than that of the control group $\left(Z=-3.927, p<0.001, \eta^{2}=0.024\right)$, and the degree of the difference between before and after the intervention for the experimental group is also larger. This indicates that the improvement in the employee engagement rating was larger for the experimental group between the two tests in comparison with the control group. However, it should be noted that the effect size is relatively small $\left(\eta^{2}=0.024\right)$ for both the experimental and the control groups (Hattie, 2009).

\section{Dimension differences between the experimental group and the control group}

The differences in the scores for the dimensions of employee engagement are presented in Table 5.

The differences in the scores of the dimensions of discretionary effort, turnover intention, rational commitment, emotional commitment, communication, perceived supervisor support and perceived team support are presented in Table 6.

The extent of the differences between the experimental group and the control group regarding discretionary effort, turnover intention, rational commitment, emotional commitment, communication, perceived supervisor support and perceived team support are presented in Table 7 and Figure 2.

Between the two years, the experimental group indicated a greater improvement regarding discretionary effort, turnover intention, rational commitment, communication and perceived supervisor support.

The control group, on the other hand, indicated a greater improvement between the two years regarding emotional commitment and perceived team support. Turnover intention deteriorated for the control group. The extent of the differences between the improvement in the experimental group and control group between the two years are presented in Table 7 and Figure 2. 
TABLE 5: Experimental group comparison between the two years.

\begin{tabular}{lccc}
\hline Factor & Before & After & \% Improvement \\
\hline Discretionary effort & 525 & 601 & 11.5 \\
Turnover intention & 304 & 289 & -2.3 \\
Rational commitment & 386 & 430 & 6.7 \\
Emotional commitment & 387 & 399 & 1.8 \\
Communication & 104 & 139 & 5.3 \\
Perceived supervisor support & 268 & 281 & 2.0 \\
Perceived team support & 256 & 259 & 0.5 \\
\hline
\end{tabular}

TABLE 6: Control group comparison between the two years.

\begin{tabular}{lccc}
\hline Factor & Before & After & \% Improvement \\
\hline Discretionary effort & 544 & 591 & 7.1 \\
Turnover intention & 281 & 332 & 7.7 \\
Rational commitment & 406 & 438 & 4.8 \\
Emotional commitment & 379 & 417 & 5.8 \\
Communication & 119 & 141 & 3.3 \\
Perceived supervisor support & 278 & 281 & 0.5 \\
Perceived team support & 234 & 265 & 4.7 \\
\hline
\end{tabular}

TABLE 7: Extent of differences between the experimental group and the control group over two years.

\begin{tabular}{lccc}
\hline Factor & $\begin{array}{c}\text { Experimental } \\
\text { group (\%) }\end{array}$ & $\begin{array}{c}\text { Control group } \\
\mathbf{( \% )}\end{array}$ & \% Difference \\
\hline Discretionary effort & 11.5 & 7.1 & 4.4 \\
Turnover intention & -2.3 & 7.7 & -10.0 \\
Rational commitment & 6.7 & 4.8 & 1.8 \\
Emotional commitment & 1.8 & 5.8 & -3.9 \\
Communication & 5.3 & 3.3 & 2.0 \\
Perceived supervisor support & 2.0 & 0.5 & 1.5 \\
Perceived team support & 0.5 & 4.7 & -4.2 \\
\hline
\end{tabular}

\section{Discussion}

This study investigated the influence that team dialogue intervention sessions over a period of 2 years, had on employee engagement.

Overall, it can be concluded that dialogue as a team intervention that was conducted over a period of two years positively influenced the employee engagement of the team. The results should however be viewed with caution as the practical significance of the influence was relatively small.

Based on the results it could be argued that the dialogue sessions offered the teams a relative sense of psychological safety and availability, two important dimensions of employee engagement (May et al., 2004). Psychological safety is experienced when employees are prepared to share their true feelings without fearing negative consequences; this, for instance, relates to the amount of support that they perceive to be provided by their manager and the organisation (Kahn, 1990; May et al., 2004; Schaufeli \& Bakker, 2004).

Furthermore, through dialogue, the team members probably developed skills to think creatively together, to understand alternative ways of thinking and a willingness to accept differences (Schein, 1993). According to Bakker (2011), stimulating personal growth, learning and development

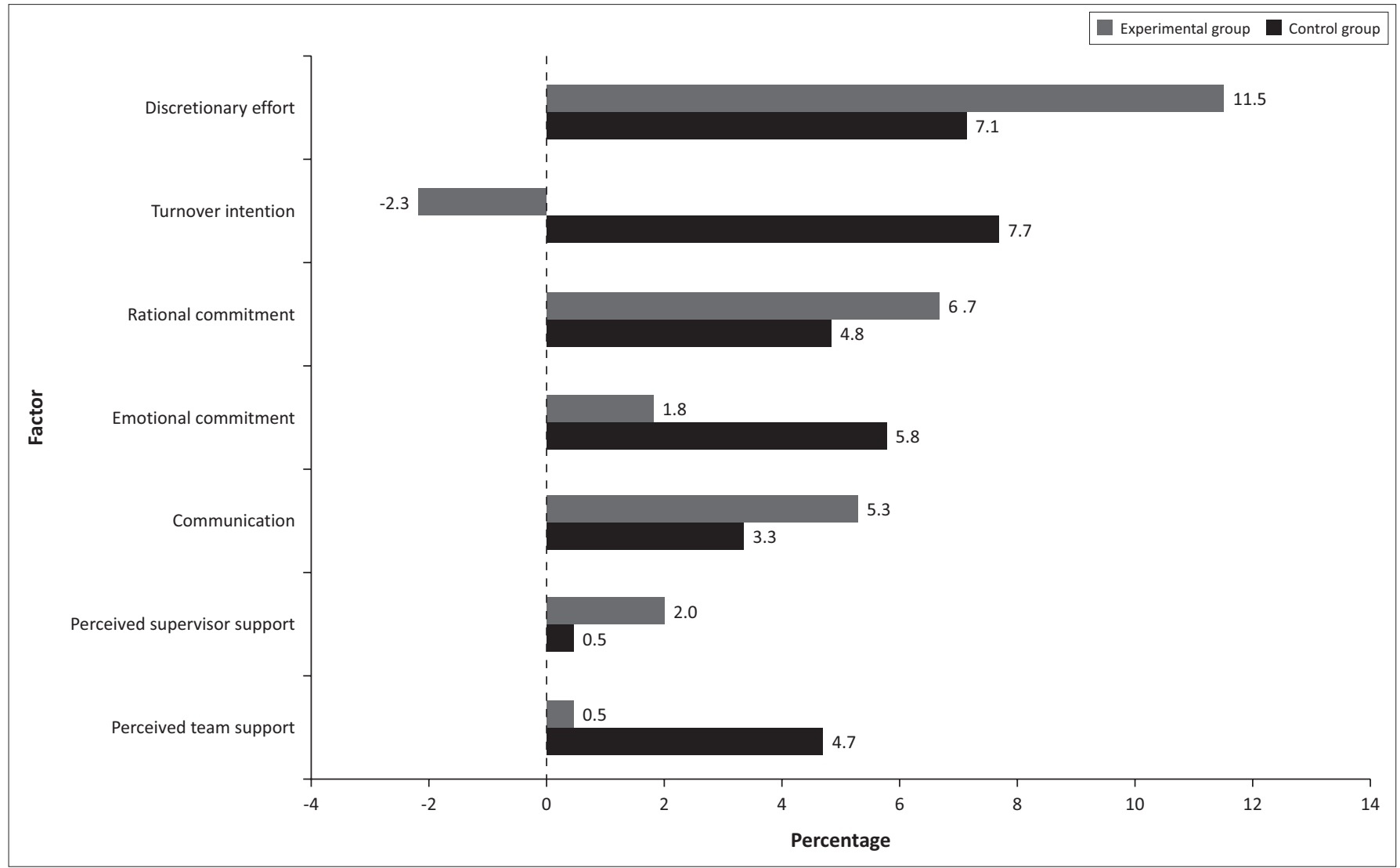

FIGURE 2: Extent of differences between experimental group and control group over two years. 
is regarded as job resources that serve as a driver for employee engagement.

\section{Dimensions}

\section{Discretionary effort}

Regarding the different dimensions, improvement in discretionary effort was rated higher by the respondents who participated in the team dialogue sessions in comparison with non-participants. Employee engagement concerns discretionary effort, where employees decide on whether to do their utmost best and put in extra effort or to do just the bare minimum of what is expected (Erikson, 2004). This result is in support of Gupta and Sharma (2016) who reasoned that engagement is a two-way process in which management puts in extra effort to engage employees and, in return, employees give the discretionary effort that motivates them to contribute to the success of the organisation and simultaneously enhance their own sense of well-being.

\section{Intention to leave}

Regarding intention to leave the organisation, the results indicated that employees who participated in the team dialogues were more inclined to stay with the organisation than those who did not participate. As dialogues create opportunities for conversation that welcomes participants to be involved in co-creating the future (Gergen et al., 2002), the dialogues could have increased the employees sense of belonging. A greater sense of belonging may lead to a decrease in withdrawal behaviour by employees. Withdrawal behaviour is one of the main ways in which employees deal with issues in the employment relationship (Lo \& Aryee, 2003). Engaging in dialoguing sessions therefore probably provided the participants with resources for connecting them with each other, including the supervisor, who represents the organisation.

\section{Rational commitment}

The improvement on rational commitment was also rated higher by members of the experimental group in comparison with the control group. Rational commitment relates to the extent to which employees believe that managers, teams and organisations are acting in their financial, developmental or professional self-interest (CLC, 2004). It would appear that the success of the team dialogue session is linked to the extent that team members were willing to create shared meaning, rather than gaining agreement on one meaning; they were accordingly more able to learn from each other and to 'crisscross' their views with each other, thus enhancing their understanding of the types of issues that impede their ability to perform (Jabri, 2004).

\section{Emotional commitment}

The dimension of emotional commitment indicated a greater improvement in the control group than the experimental group. From the results, it can be concluded that there is a possibility that the team dialogue sessions were, from an emotional commitment perspective, viewed less positively by the experimental group than the control group. Kahn (1990) suggests that engagement relates to the emotional engagement (psychological safety) of employees. This finding could be explained in the sense that members experienced less safety when others were allowed to offer viewpoints different to their own. It could also be interpreted as supporting the notion that a team's creation of shared meaning could influence the emotional commitment of individual team members and that, where a shared understanding is created, it would in turn improve rational commitment (Jabri, 2004).

\section{Communication}

The communication dimension indicated a larger improvement in the experimental group in comparison with the control group. This result corresponds with the expectation that team dialogue will improve communication among the team members. Differences and similarities in perspectives can be dealt with by allowing these differences and similarities to be shared in the open and to be modified by other data or new perspectives (Lau \& Shani, 1992). 'Such exchange is the foundation for understanding, trust, and thus effective working relations, and successful managers and employees use it frequently' (Lau \& Shani, 1992, p. 99).

Schein (1993) considers dialogue as a basic process for building common understanding, in that it allows one to see the hidden meanings of words, first by revealing these hidden meanings in our own communication. Schein (1993, p. 44) stated that 'dialogue aims to build a group that can think generatively, creatively, and most importantly, together'.

\section{Perceived supervisory support}

Perceived supervisory supports indicated greater improvement in the experimental group, with an improvement of $2 \%$, compared to the control group where the improvement was $0.5 \%$. The direct supervisors of the teams were also members of the dialogue sessions. It therefore seems that the direct dialogues through which team members, together with their supervisors, could engage in open, non-judgmental dialoguing could have created the perception that their supervisors supported them. This result is in line with research conducted by Benkoff (Dick, 2007), indicating that where employees trusted their supervisors and liked their management style, the employees shared the company's values and were proud to be employed by the company. Similarly, May et al. (2004) concluded that relationship with supervisor was a positive predictor of employee engagement.

\section{Perceived team support}

Other than expected, the improvement in perceived team support was higher for the control group in comparison with the experimental group. However, it could be reasoned that the dialogue sessions impacted prevalent group dynamics 
where the team could have been a closed knit unit before the intervention, characterised by group thinking, not allowing for differences to be expressed. This is supported by May et al. (2004), indicating that co-worker norms and self-consciousness are negative predictors of employee engagement. Lau and Shani (1992) stated:

One of the basic and most persistent problems of organisational life is that different people see situations, issues, or goals differently, depending on their particular perspectives, experiences, backgrounds, and biases - yet everyone typically assumes that everyone else sees things as they do. (p. 99)

\section{Conclusion}

In conclusion, the evidence presented by this study suggests that team dialogues, although with a small practical significance, have a positive impact in terms of improving employee engagement levels within an organisation, more specifically, on the major dimensions of discretionary effort, turnover intention, rational commitment, communication and perceived supervisory support. It is therefore, argued that dialogue sessions as applied from a social constructionist perspective could be considered a long-term intervention to enhance employee engagement.

\section{Limitations}

The score before the intervention was lower for the control group than for the experimental group. As the experimental group volunteered to be part of the intervention, these participants could have been positively biased towards the dialogue sessions. This could have influenced the impact of the intervention in both directions. For instance, employees who were not positive before the intervention, and therefore did not participate, could have found the intervention more valuable in comparison with those who did participate (because of high expectations).

A further possible limitation of this study is that both the experimental group and the control group were drawn from the same ICT sector population. Therefore, any generalisation to populations outside the ICT sector should be made with caution.

\section{Implications and recommendations}

When practised successfully, dialogue may have an influence on the level of employee engagement, as it allows groups to move beyond any one individual's understanding to gain new insights and to create ideas in ways that could not be achieved individually (Hale, 1998). Because of its centrality to team effectiveness and team learning, dialogue and the open healthy communication that allows it to occur can be considered a 'core competency' that should be aspired by the managers striving to maximise their potential (Hale, 1998).

A unique relationship develops among team members who regularly enter into dialogue, as they develop a deep trust that cannot help but carry over to discussions taking place in the team. They develop a richer understanding of the uniqueness of each person's point of view and experience how larger understandings emerge by holding one's own point of view 'gently'. Part of the vision of dialogue is the assumption of a 'larger pool of meaning' accessible only to a group. This idea, while may appear radical at first, has deep intuitive appeal for managers who have long cultivated the subtle aspects of collective inquiry (Senge, 1990).

\section{Acknowledgements Competing interest}

The authors declare that they have no financial or personal relationship(s) that may have inappropriately influenced them in writing this article.

\section{Authors' contributions}

Both authors contributed equally to the writing of this article.

\section{References}

Bakker, A.B. (2011). An evidence-based model of work engagement. Current Directions in Psychological Science, 20, 265-269. https://doi.org/10.1177/0963721411414534

Bakker, A.B. (2017). Strategic and proactive approaches to work engagement. Organizational Dynamics, 46, 67-75. https://doi.org/10.1016/j.orgdyn.2017.04.002

Brewerton, P., \& Millward, L. (2001). Organizational research methods. London: Sage.

Camargo-Borges, C., \& Rasera, E.F. (2013). Social constructionism in the context of organization development: Dialogue, imagination, and co-creation as resources of change. SAGE Open, 3(2), 1-7. https://doi.org/10.1177/2158244013487540

Cummings, T.G., \& Worley, C.G. (2015). Organization development and change (10th ed.). Stamford, CT: Cengage Learning.

Cooper, D.R., \& Schindler, P.S. (2011). Business research methods (11th ed.). Singapore: McGraw-Hill.

Corporate Leadership Council (CLC). (2004). Employee engagement survey. London: Research Corporate Executive Board.

Dick, G. (2007). The progress of female police officers? An empirical analysis of organisational commitment and tenure explanations in two UK police forces. International Journal of Public Sector Management, 20(2), 81-100. https://doi. org/10.1108/09513550710731463

Duffy, G.L., \& Wong, A.K. (2016). Complementary strengths. The Journal for Quality and Participation, 39(2), 20-22.

Easton, V.J., \& McColl, J.H. (2004). Steps statistics glossary. The University of Glasgow. Retrieved from http://www.stats.gla.ac.uk/steps/glossary/nonparametric.html

Ellinor, L., \& Gerard, G. (1998). Dialogue: Rediscover the transforming power of conversation. New York: Wiley.

Erikson, B. (2004). Nature times nurture: How organizations can optimize their people's contribution. Journal of Organizational Excellence, 24(1), 21-30. https:// doi.org/10.1002/npr.20034

Geldenhuys, D.J. (2015). Relational constructionism and relational practices as a paradigm for organisational psychology in the South African context. SA Journal of Industrial Psychology/SA Tydskrif vir Bedryfsielkunde, 41(1), Art. \#1225, 1-10. Industrial Psychology/SA Tydskrif vir Bed
https://doi.org/10.4102/sajip.v41i1.1225

Gerard, G., \& Teurfs, L. (1995). Dialogue and organizational transformation. In K. Gozdz (Ed.), Community building: Renewing spirit and learning in business (pp. 143-153). San Francisco, CA: New Leaders Press.

Gergen, K.J., McNamee, S., \& Barrett, F.J. (2002). Realizing transformative dialogue. In N.C. Roberts (Ed.), The transformative power of dialogue (pp. 77-105). Oxford, UK: Elsevier Science.

Gupta, N., \& Sharma, V. (2016). Exploring employee engagement - A way to better business performance. Global Business Review, 17(3), 45-63. https://doi.org/ $10.1177 / 0972150916631082$

Hale, J.P. (1998). The theory and practice of dialogue in organisational settings. CCO Research Paper. Retrieved from http://www.workteams.unt.edu/literature/paperjhale.html

Harter, J.K., Hayes, T.L., \& Schmidt, F.L. (2002). Business-unit-level relationship between employee satisfaction, employee engagement, and business outcomes: A meta-analysis. Journal of Applied Psychology, 87(2), 268-279. https://doi.org/ 10.1037/0021-9010.87.2.268

Hattie, J. (2009). Visible learning. London: Routledge.

Herrera, D. (2015). The record company as a learning structure: Identifying performance and learning inhibitors. Journal of the Music and Entertainment Industry Educators Association, 15(1), 121-146. https://doi.org/10.25101/15.6 
Isaacs, W.S. (1994). Team learning. The fifth discipline fieldbook: Strategies and tools for building a learning organization. New York: Doubleday.

Jabri, M. (2004). Team feedback based on dialogue implications for change management. Journal of Management Development, 23(2), 141-151. https://doi. org $/ 10.1108 / 02621710410517238$

Kahn, W.A. (1990). Psychological conditions of personal engagement and disengagement at work. Academy of Management Journal, 33, 692-724. https:// doi.org/10.2307/256287

Lau, J.B., \& Shani, A.B. (1992). Behaviour in organisations. An experiential approach (5th ed.). Boston, MA: Irwin.

Leiter, M.P., \& Maslach, C. (2004). Areas of worklife: A structured approach to organizational predictors of job burnout. In P. Perrewé \& D.C. Ganster (Ed.), Research in occupational stress and wellbeing (Vol. 3, pp. 91-134). Oxford, UK: Elsevier.

Lo, S., \& Aryee, S. (2003). Psychological contract breach in a Chinese context: An integrative approach. Journal Management Studies, 40, 1005-1020. https://doi. org/10.1111/1467-6486.00368

Markos, S., \& Sridevi, M.S. (2010). Employee engagement: The key to improving performance. International Journal of Business and Management, 5(12), 89-96.

Maslach, C., Schaufeli, W.B., \& Leiter, M.P. (2001). Job burnout. Annual Review of Psychology, 52, 397-422. https://doi.org/10.1146/annurev.psych.52.1.397

May, D.R., Gilson, R.L., \& Harter, L.M. (2004). The psychological conditions of meaningfulness, safety and availability and the engagement of the human spirit at
work. Journal of Occupational and Organizational Psychology, 77, 11-37. https:// work. Journal of Occupational and Orga
doi.org/10.1348/096317904322915892

Organ, D. (1997). Organizational citizenship behaviour: It's construct clean-up time Human Performance, 10(2), 85-97. https://doi.org/10.1207/s15327043hup1002_2

Pallant, J. (2007). SPSS survival manual: A step by step guide to data analysis using SPSS for windows (3rd ed.). England: McGraw Hill Open University Press Milton Keynes, UK.

Robinson, D., Perryman, S., \& Hayday, S. (2004). The drivers of employee engagement IES report 408. Retrieved from http://www.employment-studies.co.uk/summary/ summary. php?id=408
Rothbard, N.P., (2001). Enriching or depleting? The dynamics of engagement in work and family roles. Administrative Science Quarterly, 46, 655-684. https://doi. org/10.2307/3094827

Saks, A.M. (2006). Antecedents and consequences of employee engagement. Journal of Managerial Psychology, 21(7), 600-619. https://doi.org/10.1108/026839406 10690169

Schaufeli, W.B. (2013). What is engagement? In C. Truss, K. Alfes, R. Delbridge, A. Shantz, \& E. Soane (Eds.), Employee engagement in theory and practice. London: Routledge, 1-2 http://www.wilmarschaufeli.nl/publications/Schaufeli/414.pdf

Schaufeli, W.B., \& Bakker, A.B. (2004). Job demands, job resources and their relationship with burnout and engagement: A multi-sample study. Journal of Organizational Behavior, 25(3), 293-315. https://doi.org/10.1002/job.248

Schaufeli, W.B., Salanova, M., González-Romá, V., \& Bakker, A.B., (2002). The measurement of engagement and burnout: $A$ confirmative analytic approach. Journal of Happiness Studies, 3, 71-92. https://doi.org/10.1023/A:1015630930326

Schein, E. (1993). On dialogue, culture and organizational learning. Organizational Dynamics, 21, 40-51. https://doi.org/10.1016/0090-2616(93)90052-3

Senge, P.M. (1990). The fifth discipline: The art and practice of the learning organisation. New York: Currency-Doubleday.

Sidebottom, J. (2015). Six ways to develop high-performance teams. Consulting Specifying Engineer. Retrieved from https://0-search.proquest.com.oasis.unisa. ac.za/docview/1738105364?accountid $=14648$

Simpson, M.R. (2009). Engagement at work: A review of the literature. International Journal of Nursing Studies, 46(7), 1012-1024. https://doi.org/10.1016/j.ijnurstu. 2008.05.003

Tett, R.P., \& Meyer, J.P. (1993). Job satisfaction, organisational commitment, turnover intention and turnover: Path analysis based on meta-analytic findings. Personne Psychology, 46(2), 259-293. https://doi.org/10.1111/j.1744-6570.199 3.tb00874.x

Van der Colff, J.J., \& Rothmann, S. (2009). Occupational stress, sense of coherence, coping, burnout and work engagement of registered nurses in South Africa. SA Journal of Industrial Psychology, 35(1), 1-10. Retrieved from http://www.scielo.org. $\mathrm{za} /$ scielo.php?script=sci_arttext\&pid=S2071-07632009000100001\&lng=en\&tlng=pt 